\title{
TEACHERS PERFORMANCE MANAGEMENT SYSTEM SATISFACTION: THE CASE EVIDENCE OF SAUDI MINISTRY OF EDUCATION
}

\author{
NADA ALSHAIKHI, PhD
}

Swansea University, United Kingdom

DOI: 10.46609/IJSSER.2020.v05i08.009 URL: https://doi.org/10.46609/IJSSER.2020.v05i08.009

\begin{abstract}
Performance management systems (PMSs) are an important part of human resource management in any organisation and play an authoritative role. Performance management (PM) is now seen as a strategic initiative to enhance employee performance and consequently that of the organisation. Such a strategy is possible when management uses the information generated by PM to determine employees' past, present and future performance. Although educational organisations are different from other organisations in terms of their activities, the management structures do not differ much. Thus, educational institutions face the same administrative issues as other organisations, including the issues related toPMSs. This study examined teachers' perspectives of the determinants of teachers' performance management satisfaction in the Saudi Ministry of Education. The main aim of this study is to analyse the factors influencing the effectiveness of the PMS, it also to develop a conceptual framework of how effective performance management system lead to teachers' satisfaction and loyalty and commitment in achieving the organisational goals. This is accomplished through a self-administered questionnaire survey of teachers, designed to measure teachers' opinions of the performance management system. A total of 502 teachers completed the survey. The findings of the study demonstrate that an accurate performance management system should comprise aspects such as strategic planning and goalsetting, ongoing feedback, clear and balanced performance appraisal (PA), fairness of PAs, pay for performance, training and development, promotion decisions, management commitment, involvement in the PM process and understanding of the purpose of the PMS.
\end{abstract}

Keywords: Performance management system, Ministry of education, performance appraisal. 


\section{International Journal of Social Science and Economic Research}

ISSN: $2455-8834$

Volume:05, Issue:08 "August 2020"

\section{INTRODUCTION}

Enhancing performance is the main aim of most organisations today, and performance management (PM) is part of a link between organisational strategy and results (Bhatia, 2006). Walters (1995) defines PM as the 'process of directing and supporting employees to work as effectively and efficiently as possible in line with the needs of the organisation'. According to Williams (2002), the aims of PM are to create a shared vision of the goals and objectives of an organisation and to help employees to understand and recognise their duties and responsibilities in contributing to managing and improving both themselves and their organisation.

Educational institutions, including schools around the world, face major challenges in providing quality education (Darling-Hammond \& Richardson, 2009). Therefore, most educational planners and policy makers have made PM a tool for teachers' professional development, with the goal of raising the quality of education. Thus, one of the most crucial factors that may improve teachers' performance is an effective PMS. This system is capable of influencing teachers' behaviour and improving school performance (Gentle, 2001). Tomlinson (2000) views $\mathrm{PM}$ as a tool that helps the continuous improvement of teachers' performance, along with the development of competence and realisation of potential, noting that PM is about setting expectations and plans and helping teachers to work as professionals. Gentle (2001) argues that PM should permeate the school environment on a daily basis and should not be seen as a simple one-off event of filing out an annual performance form. Furthermore, Gentle (2001) argues that PM should be used to help individuals understand what their organisation is trying to achieve and how this can be accomplished. PM is a means of managing individuals to ensure that organisational objectives are met through appropriate tasks, so in schools PM can be described as a mechanism to improve and develop teaching and learning. A well-designed teacher PMS enables school management to evaluate teachers' performance, identify and encourage good performance, recognise areas for development and improve teachers' overall performance (Tomlinson, 2000).

As with businesses, educational organisations also need PM to improve the quality of education provided and thus meet organisations' expectations. Upper management in educational institutions need to acquire the competencies for designing and implementing effective PMSs (Darling-Hammond \& Richardson, 2009). Designing and implementing a poor PMS can result in inaccurate evaluations and low levels of employee loyalty, commitment, motivation and satisfaction (Elliott, 2015). Accordingly, unclear objectives and a lack of understanding about the main elements of PM are the main reasons behind PM schemes' failure to meet expectations and employees dissatisfaction.

Researchers have found that individuals' satisfaction with PMSs plays an important role in developing functional and organisational attitudes and enhancing motivation to increase performance (Taylor et al., 1995). According to Cardy and Dobbins, (1994) when employees 


\section{International Journal of Social Science and Economic Research}

ISSN: $2455-8834$

Volume:05, Issue:08 "August 2020"

believe the PMS is biased and unfair, this can be a source of employee dissatisfaction with the system. Employees' attitudes towards the PMS are a critical aspect of the effectiveness of the system. Dissatisfaction and perceptions of injustice and inequality in evaluations might lead to the failure of the system. Dissatisfaction with the procedures may lead to employee turnover and lack of motivation; it can also be difficult to link performance to reward if the appraisee experienced inadequate satisfaction with the process (Cawley et al., 1998). Satisfaction in relation to PMSs is an important factor that influences employees' productivity, motivation and commitment. Such systems are designed to motivate employees to achieve organisational goals (Mohrman\& Lawler, 1998). This study examined teachers' perspectives of the determinants of teachers' performance management satisfaction in the Saudi Ministry of Education. The main aim of this study is to analyse the factors influencing the effectiveness of the performance management systems, it also to develop a conceptual framework of how effective PMSs lead to teachers' satisfaction and loyalty and commitment in achieving the organisational goals.

\section{LITERATURE REEVIEW}

PM has been defined by Armstrong (2009, p. 1) as a 'systematic process to improve the performance of a company by developing the individual's and team's performance. To reach these outcomes PM should be understood and implemented using an agreed framework of planned goals, standards and competency requirements'. PM is an instrument used to assess and improve the effectiveness of individuals in the workplace, an effective PM process, in terms of formal use, helps the administrative and human resource departments in determining promotions, remuneration and compensation. It also simplifies the function of human resources in determining and evaluating HR programmes for training needs (Anderson, 1993). In other words, by analysing the results of PM, HR departments can unveil both the weaknesses and strengths of their employees and involve them in appropriate training programmes to help them maintain the required quality of work.A PMS is considered one of the most complicated policies in any organisation (particularly in the public sector due to the intangible nature of many public organisations). In practice, the outcomes of PM in most organisations are often unsatisfactory, with both employees and managers holding negative perceptions about them and most managers relying on their personal experience when judging employees, so the process loses objectivity. In fact, Grint(1993, p. 64) wrote that "rarely in the history of business can such a system have promised so much and delivered so little". PM and PA have long been the subject of criticism: over half a century ago, MacGregor (1957) noted limitations about appraisers and supervisors 'playing god' and undertaking mysterious personality evaluations instead of concentrating on job performance. Many managers and employees have reservations about the ability of PMS to serve its intended purposes as there are specific problems which may negatively affect the efficiency of the process. Performance management systems are generally important for employees' 
International Journal of Social Science and Economic Research

ISSN: 2455-8834

Volume:05, Issue:08 "August 2020"

development, motivation and retention. Such results will not be obtained if individuals are not satisfied with the process. When individuals perceive the system unfair and dissatisfied with the system, they will be less likely to use performance evaluations as feedback to improve their performance (Ilgen, et al., 1979). Employees perceive a PMS to be a form of management surveillance and control ifthey do not accept it, and they may perceive the PM process as a form of surveillance and administrative control that is used to monitor performance and increase their administrative and compliance burdens. This is likely to manifest itself as negative attitudes about the PM process and make employees feel they are under a spotlight in front of management when they are appraised (Prowse and Prowse, 2009, p. 72). Due to work pressure, deadlines and time constraints, employees may view the administrative tasks related to the PMS as of secondary priority and perhaps even resist them altogether (de Waal and Counet, 2009, p. 368). bureaucratic culture to a more modern, performance-oriented culture that drives employees to accept performance systems as they are seen to be beneficial for all (Brudan, 2010, p. 116). Satisfaction with PMSs is an important factor influencing productivity, motivation and employees' commitment. Such systems are designed to motivate employees to achieve organisational goals. Unless employees are satisfied with these systems and support them, the systems will ultimately be unsuccessful (Mohrman and Lawler, 1981).

\section{ADAPTION OF THE CONCEPTUAL FRAMEWORK}

This study investigates how effective PM can lead to teacher satisfaction with PM and positive performance and how these can be related to variables such as strategic planning and goal setting; on-going feedback; PA processes; pay-for-performance; training and development needs; promotion; management commitment; the perceived fairness of PM; teachers' involvement in developing PM; and teachers' awareness of the purpose of PMSs. How these variables affect the PMSs used for teachers in the Saudi education sector, as perceived by teachers, is thus investigated. The relationships in the hypothesised model of study are conceptually defined in Figure 1. 
International Journal of Social Science and Economic Research

ISSN: 2455-8834

Volume:05, Issue:08 "August 2020"

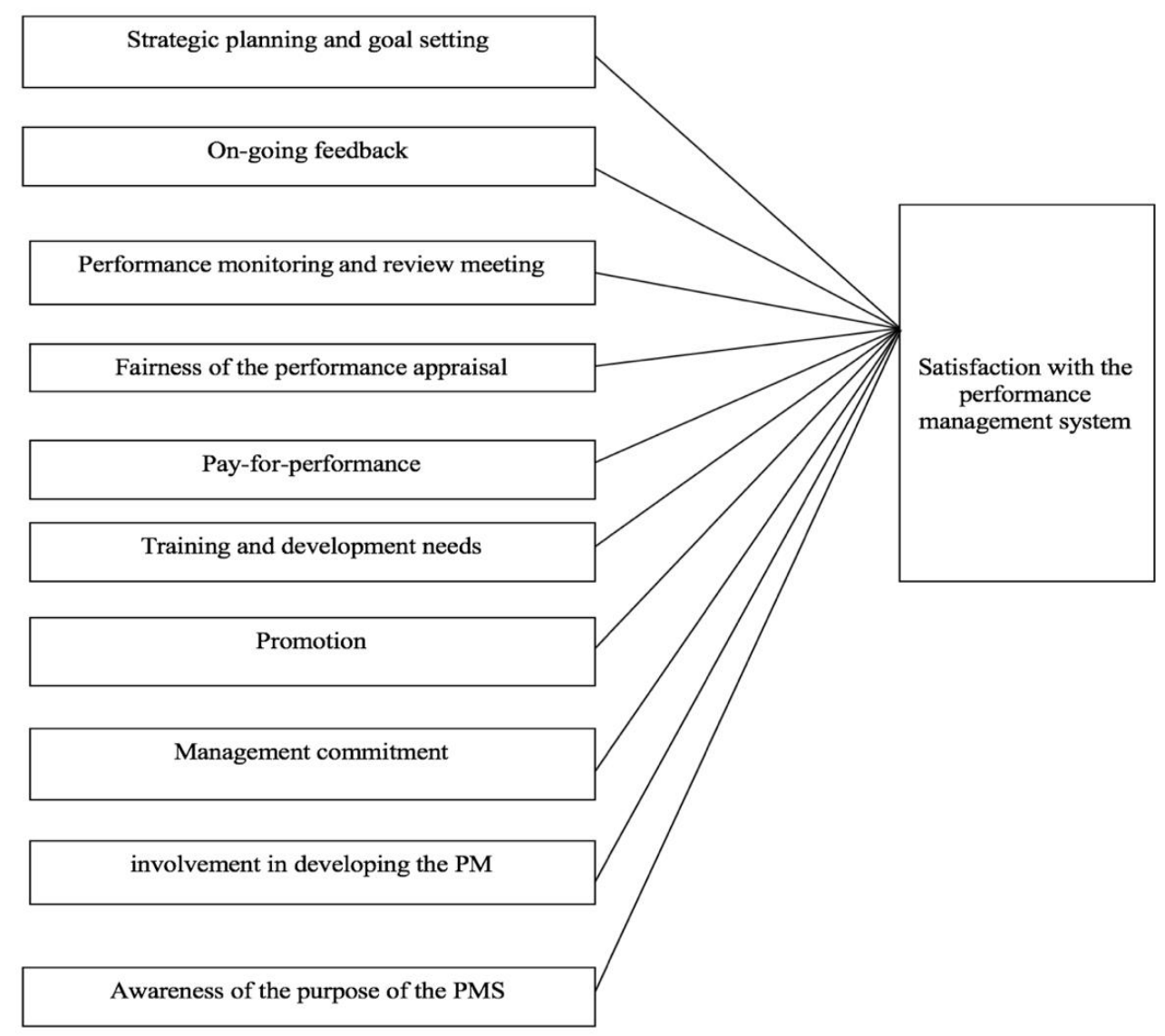

Figure 1 Hypothesised model of study

\subsection{Strategic planning and goal setting}

According DeCenzo et al. (2015) stated that PMSs enable employees to participate in goal setting in order to improve their commitment to their performance. He added that organisational goals should be transformed into individual goals to better integrate employees and the organisation. This relates positively with employee behaviour, which, in turn, has the most direct relationship with organisational performance, as well as greatly being able to determine an employee's satisfaction. Goal-setting theory argues that appraisal criteria and performance objectives should be clear and understandable in order to motivate employees. If performance goals are clearly set out and linked to individuals' goals, everyone can work towards the successful outcomes of these plans (Locke \& Latham, 2002). Employees with clear objectives are far more motivated to execute their duties well and show more job satisfaction than those without them (DeCenzo et al., 2015). When employees believe that they are able to achieve performance objectives, it gives them a feeling of satisfaction. Employees with unknown 


\section{International Journal of Social Science and Economic Research}

ISSN: $2455-8834$

Volume:05, Issue:08 "August 2020"

performance objectives and tasks have lower performance than their colleagues who have relatively clear goals and objectives. Hence, the following hypothesis can be formulated:H1: Strategic planning and goal setting is significantly and positively related to PMS satisfaction.

\subsection{Feedback}

Feedback is the information that employees receive about their performance, behaviours and attitudes and about how others are assessing this information, which is considered to be a significant factor of any effective PMS in organisations (DeNisi \&Sonesh, 2011). Feedback is an important organisational resource that managers can use to "motivate, direct, and instruct the performance of subordinate members" towards organisational goal achievement (Ashford \& Cummings, 1983, p. 371). Providing feedback for employees has strategic value for organisations (Steelman \& Rutkowski, 2004), and therefore, it is important to understand its role in improving employees' performance and the work outcomes in organisations, in order to better direct it towards the achievement of organisational goals. Additionally, Deci and Ryan (2000) identified that open communication with managers and employees does not result in negative perceptions; it is an important factor that leads to improvements in employees' attitudes towards PMSs. In the same vein, Robertson and Stewart (2006) stated that managers who provide honest and accurate feedback were considered to be more procedurally and informationally fair. Hence, the following hypothesis can be formulated:H2: On-going feedback is significantly and positively related to PMS satisfaction.

\subsection{Accurate and balanced PA process}

Henderson (1984) says that an effective performance review should be based on measuring an employee's contribution to the job instead of the employee's activities or personality. When a performance review is conducted, individuals' performance should be measured against performance standards (Aguinis, 2015) as employees cannot be expected to work effectively if they are not aware of what they are to be evaluated against. So, precise performance results can lead to accurate HR decisions regarding areas such as rewards, training, promotion and transfer and termination decisions, which, in turn, can lead to increased employee motivation and commitment to organisational goals and, ultimately, to satisfaction with PMSs. According to Igbojekwe et al. (2015), the failure to match performance standards and performance goals and objectives leads to misunderstandings, poor morale, a lack of job satisfaction and ineffectiveness. Dissatisfaction with evaluations may lead to a decline in motivation and a sense of injustice. The lack of accurate results relating to the evaluation process will make it difficult to link performance to administrative decisions, such as promotions, rewards, training and development (Lawler, 1967). Studies have shown that the accuracy of appraisal results has an impact on 


\section{International Journal of Social Science and Economic Research}

ISSN: $2455-8834$

Volume:05, Issue:08 "August 2020"

satisfaction and, hence, on factors such as productivity, motivation and organisational commitment (Cawley et al., 1998). Appraisal systems are designed to motivate employees and direct their efforts towards achieving goals. If they are not accurate, there will be no satisfaction on the part of the staff, and they will not support its implementation, and therefore, it will not succeed in the end (Mohrman\& Lawler, 1981). Hence, the following hypothesis can be formulated:

H3: Clear and accurate performance appraisal processes are significantly positively related to teachers' satisfaction with PMSs.

\section{Perceived fairness of PA}

In a PM process, employee attitudes towards the system are significantly correlated with the satisfaction with the system. According to Boswell and Boudreau (2002), employees' perceptions of the fairness of the PA process are considered an important factor that contributes to its success. Employee perceptions of the fairness of the system have an influence on the effectiveness of the system because fairness is related to the confidence in and, therefore, the satisfaction with the system (Kavanagh et al., 2007). A study conducted by Landy et al. (1978) on the perceived fairness and accuracy of appraisal systems found that the value of a system not only relies on the physical characteristics of the appraisal tools but may also be influenced by the perceived fairness of the process. Patrick and Ozturen (2014, p. 965) stated that "employees are believed to show a positive reaction towards their jobs if they perceive fair treatment of the appraisal system in the workplace. Furthermore, the workers' reaction towards the appraisal mechanism plays a crucial role in overall job satisfaction". Hence, the following hypothesis can be formulated: H4: The fairness of performance appraisal is positively and significantly related to satisfaction with the PM process.

\subsection{Pay for performance (PFP)}

PFP is defined as pay for employees according to their perceived merit, rather than their length of service, qualifications and other attributes (Stone, 2008), and its main aim is to retain and motivate employees. Heneman and Gresham (1998) stated that it is the way that organisations reward their employees for their time and hard work. Supporters of PFP claim that rewarding employees for good performance helps in attracting, retaining and motivating employees (Wragg et al., 2004). Thus, the reward can be seen as an important element in determining the motivational value of the reward. In addition, there is a strong belief that when highly skilled qualified employees are rewarded based on their performance, they are attracted to the organisation and want to remain with it as long as possible. Based on self-efficacy expectancy theory (Vroom, 1964), rewards motivate employees to work harder and thus improve 


\section{International Journal of Social Science and Economic Research}

ISSN: $2455-8834$

Volume:05, Issue:08 "August 2020"

performance as promotion and punishment guide human behaviour. Individual performance will improve when rewards are highly related to performance. Additionally, behavioural management theory (Lehman \& Geller, 2004) states that PFP enhances the efforts of individuals and thus improves performance. Therefore, there is a direct correlation between PFP and increased organisational commitment and employee satisfaction (Moon, 2000; Murlis, 1992; Murnane \& Cohen, 1986). Hence, the following hypothesis can be formulated: H5: Pay-for-performance is significantly and positively related to teachers' satisfaction with PMSs.

\subsection{Training and development needs}

A PMS encourages individuals and the organisation to improve overall performance and growth, and it plays an important role in determining the training and development that individuals and groups require (Adhikari, 2010).Coelho and Moy (2003) further stated that the stability of an organisation is closely linked with the continuous improvement of the performance of its staff, so organisations invest time and money in determining the method that can best improve performance through the selection of a well-designed PMS.Various research indicates the positive impact of training on employee productivity, and it is considered to be the most widespread way of improving the productivity and performance of individuals. Investing in improving the performance of employees and training them in teamwork and problem solving has a positive impact on the growth of organisations as well as on the work of employees. According to Kabaka et al., (2014), studies indicate that employee training and development lead to job satisfaction. Training lends a hand to employees as it helps them in their development and growth. Hence, it is important that training also motivates them to achieve organisational goals and objectives (Raziqa\& Maulabakhsh, 2015). Appropriate training based on evaluation results gives employees a sense that the evaluation process is fair and thus improves their attitudes towards the PM process as a whole. The main purpose of a PMS is improving employees' performance, and when employees are aware of the main purpose of the process, their satisfaction with the process will increase. Hence, the following hypothesis can be formulated: H6: There is a significant relationship between training and teachers' satisfaction with PMSs.

\subsection{Promotion}

Promotion on the basis of PM results is also a very common method, whereby the best performing employees are moved to higher positions. It leads to employee satisfaction and motivation with higher pay and duties. According to Hannagan, (2002), promotion builds employee loyalty, reduces employee turnover, encourages self-development and creates an interest in training and development. If the promotions are well implemented, they may lead to increased motivation. However, some organisations do not commit to the promotion procedures, 


\section{International Journal of Social Science and Economic Research}

ISSN: $2455-8834$

Volume:05, Issue:08 "August 2020"

which results in a lack of employee satisfaction. Therefore, clear promotion policies should be put in place. Promotions based on merit are carried out by many organisations as a way of stimulating better performance. Promotions based on merit are seen as a fair way of rewarding employees with high performance, thus encouraging all employees to strive for better performance. it provides employees with functional and moral satisfaction and increase the productivity of the organisation as its growth needs can be met with existing staff: Promotions that take place within an organisation reduce employee turnover and training and recruitment costs (Hannagan, 2002). Hence, the following hypothesis can be formulated: H7: There is a significant relationship between training and teachers' satisfaction with PMSs.

\subsection{Management commitment}

Abu Mansor et al. (2012), in their study about the determinants of PMSs, stated that the implementation of a PMS in an organisation is largely affected by management commitment. Therefore, management must be committed to implementing performance management, be responsible for this applied system and be able to invest its resources to achieve the desired benefits of the system, otherwise the system will be considered a waste of time, and neither the employees nor the organisation will experience success through the implementation of the system. Du Plessis (2007) states that the implementation of a PMS usually faces resistance from employees. In order to mitigate this resistance, management should be well trained and committed to the implementation process to gain maximum benefit. If the information is insufficient and there are political complications in performance management systems, through adequate management it can still provide effective guidance and a means of control, which can improve PM results and, in turn, employee satisfaction. According to De Waal and Counet's (2009) study, management commitment to the implementation of performance management systems will result in effective PM that improves the performance and overall quality of employees' performance and in gains in employee satisfaction. When management is committed to PM processes, such as goal setting, giving feedback, and providing accurate PM results, which are followed up by the appropriate HR decisions, such as those relating to rewards, promotions and training, employee satisfaction with PMSs will definitely increase. Hence, the following hypothesis can be formulated: H8: Management commitment to the PM process is positively related to satisfaction with the PM process.

\subsection{Involvement in developing PMSs}

When reviewing the literature, researchers in the field of participation in decision-making prove that greater participation leads to greater employee satisfaction. Jones (1997) stated that participants' experiences shorten time and provide information on what should be applied or 


\section{International Journal of Social Science and Economic Research}

ISSN: $2455-8834$

Volume:05, Issue:08 "August 2020"

avoided, what strategies are successful and what are the best ways to meet the needs of participants. Therefore, when employees are involved in the development of PMSs, evaluation standards and procedures, the likelihood of satisfaction and acceptation is very high. Fullan and Hargreaves (1996) argue that there may also be a fear of change, which alienates individuals from reforming practices at work and is offset by resistance or the unwillingness to change, and this may affect the success of the initiative. Therefore, there is a need to involve employees in the design, development and implementation of PMSs. Aguinis (2015) emphasised that it is necessary to involve employees in the PM process because it gives them a sense of fairness and a feeling of security regarding the process. Their involvement also increases the teachers' commitment to meeting performance objectives. Additionally, according to Murphy and Cleveland (1995), individuals' satisfaction with the PM process usually depends on their involvement in setting the PM standards. They also feel satisfied when they have enough comprehensive knowledge of PM standards and procedures. It is against this background that many researchers support greater employee involvement in the development of PM procedures and criteria; in this way, the PM process can be a more constructive process that enhances the professional development of individuals (Mo et al., 1998; Stiggins \&Bridgeford, 1985). Hence, the following hypothesis can be formulated: H8: Involving teachers in designing the criteria for performance will lead to teachers' satisfaction with the PM process.

\subsection{Awareness of the purpose of PMSs}

Usually, training for appraisers in the PM process is emphasised, and employee training in this area is frequently overlooked (McMahon, 2009). In this regard, the importance of informing employees about the system's objectives, their role in them and the best practices for receiving feedback and interacting with management should not be underestimated. Indeed, if employees have this information, it might reduce their resistance to the PMS and increase acceptance. Employees themselves may lack training on the importance of such systems in improving their performance, how to set objectives and how to prepare for performance review meetings (Fryer et al., 2009). Management should therefore be responsible for educating employees to improve their attitude towards PM by emphasising its benefits to them, such as in terms of developing their skills, identifying their training needs and examining their suitability for pay rises or other rewards. Management should ensure that employees are involved in the PM process and aware of the advantages provided by the PMS. Employees should understand that the PM is not being conducted to find mistakes but, instead, to improve teacher performance through identifying development and training needs. According to Patrick and Ozturen (2014), individuals are thought to react positively towards their PMS if they understand its purpose in the workplace. Furthermore, this reaction plays an important role in their overall job satisfaction. Hence, the 
International Journal of Social Science and Economic Research

ISSN: 2455-8834

Volume:05, Issue:08 "August 2020"

following hypothesis can be formulated: H10: Teachers' awareness of the purpose of PMSs will lead to an improvement in teachers' attitudes towards the PM process.

\section{METHODOLOGY}

As mentioned above, the main aim of this research study is to investigate the factors and determinants affecting satisfaction with the teachers' PM system in a Saudi setting. This study follows a quantitative approach to achieve the research aims. This is achieved by measuring participants' perceptions of the identified research questions. Primary data was collected using a questionnaire, the study explores participants' opinions and evaluates the perceptions of Saudi public schoolteachers in relation to PMS issues. This makes it possibleto achieve the aims and objectives of the study and to test the proposed hypotheses. Thus, a questionnaire was developed to gather primary data related to the topic. Statistical methods are also introduced to analyse the collected data. This study was carried out using data from male and female teachers from all Saudi regions. The total number of completed surveys returned was 502. The quantitative research method is used to shed light on the nature of the PMS practices existing in the Saudi Ministry of Education and their effectiveness. In particular, the quantitative research approach facilitates the investigation into and measurement of teachers' views on the PMS process and the extent to which the process influences teachers' job satisfaction. In this study, a web-based survey was used to collect data, due to the ease in reaching the largest number of teachers. Then, a five-point Likert scale was used to check the respondents' beliefs and opinions about their satisfaction with and acceptance of the PMS.

\section{DADA ANALYSIS}

The main reason for this research study was to identify and examine factors affecting Saudi teachers' satisfaction with the PMS. Here, two distinct statistical software tools were used to achieve the main study goals. Statistical product and service solution (SPSS) was used to analyse the preliminary data, while AMOS was deployed for structural equation modelling (SEM).

\subsection{Descriptive Statistics Analysis and Correlation}

Percentage, means, standard deviation and Pearson's correlations for each factor are presented in the following tables.

\section{- Strategic planning and goals setting}


International Journal of Social Science and Economic Research

ISSN: 2455-8834

Volume:05, Issue:08 "August 2020"

Percentage, the means, standard deviation and Pearson's correlations for strategic planning and goals setting are presented on table 1.1 The average mean is 4.30 with small standard deviations and fairly moderate correlation.

Table 1-1 Descriptive statistics and correlations of the perception of Strategic planning and goals setting

\begin{tabular}{|c|c|c|c|c|c|c|c|c|c|c|c|}
\hline \multirow[t]{2}{*}{ Questions Items } & \multirow[t]{2}{*}{ Mean } & \multirow[t]{2}{*}{ SD } & \multicolumn{5}{|c|}{ Percentage } & \multirow[t]{2}{*}{1} & \multirow[t]{2}{*}{2} & \multirow[t]{2}{*}{3} & \multirow[t]{2}{*}{4} \\
\hline & & & S/D & $\mathrm{D}$ & $\mathrm{U}$ & $\mathrm{A}$ & S/A & & & & \\
\hline $\begin{array}{l}\text { Individual performance } \\
\text { should be aligned to } \\
\text { organizational mission } \\
\text { and objectives }\end{array}$ & 4.28 & .871 & 2.2 & 3.0 & 5.6 & 42.6 & 46.6 & - & & & \\
\hline $\begin{array}{l}\text { clear Mission and vision } \\
\text { should direct teachers to } \\
\text { achieve organisational } \\
\text { goals }\end{array}$ & 4.30 & .805 & 1.4 & 3.0 & 4.4 & 46.2 & 45.0 & $.808 * *$ & & & \\
\hline $\begin{array}{l}\text { An important aspect of } \\
\text { performance management } \\
\text { is the setting of goals and } \\
\text { objectives }\end{array}$ & 4.31 & .874 & 3.0 & 1.8 & 4.0 & 43.2 & 48.0 & $.813 * *$ & $.849 * *$ & & \\
\hline $\begin{array}{l}\text { Performance expectations } \\
\text { need to be set at the } \\
\text { beginning of the year in } \\
\text { alignment to strategic } \\
\text { objectives }\end{array}$ & 4.32 & .894 & 2.6 & 3.4 & 3.4 & 41.0 & 49.6 & $.745^{* *}$ & $.869^{* * *}$ & $.792^{* *}$ & - \\
\hline
\end{tabular}

\section{- On- going feedback}

Percentage, means, standard deviation and Pearson's correlations for On- going feedback are presented on table 1.2. The average mean is 4.34 with small standard deviations and fairly moderate correlation.

Table 1-2 Descriptive statistics and correlations of the perception of on-going feedback

\begin{tabular}{|l|c|c|c|c|c|c|c|c|c|c|}
\hline \multicolumn{1}{|c|}{ Items } & Mean & SD & \multicolumn{3}{|c|}{1} & \multicolumn{2}{|c|}{2} & 2 & 3 \\
\cline { 4 - 8 } & & & S/D & D & U & A & S/A & & & \\
\hline $\begin{array}{l}\text { Constructive feedback helps } \\
\text { teachers to improve their } \\
\text { performance }\end{array}$ & 4.32 & .894 & 3.0 & 3.8 & 3.0 & 45.0 & 45.2 & - & & \\
\hline $\begin{array}{l}\text { Giving Feedback in periodic } \\
\text { clarifies teachers' weakness and } \\
\text { strengths }\end{array}$ & 4.26 & .915 & 1.6 & 2.4 & 4.6 & 41.2 & 50.2 & $.768^{* *}$ & - & \\
\hline $\begin{array}{l}\text { On-going feedback helps to } \\
\text { improve the communication }\end{array}$ & 4.36 & .811 & 1.8 & 3.6 & 3.8 & 33.7 & 57.2 & $.779^{* *}$ & $.705^{* *}$ & - \\
\hline
\end{tabular}


International Journal of Social Science and Economic Research

ISSN: 2455-8834

Volume:05, Issue:08 "August 2020"

between teachers and head

teacher

Note: $\mathrm{N}=502$ and $* *$ correlation is significant at the 0.01 level (2-tailed) and *at the 0.05 level (2-tailed).

\section{- Performance appraisal process}

Percentage, means, standard deviation and Pearson's correlations for On- going feedback are presented on table 1.3. The average mean is 4.34 with small standard deviations and fairly moderate correlation.

Table 1-3 Descriptive statistics and correlations of the perception of PA stage

\begin{tabular}{|c|c|c|c|c|c|c|c|c|c|c|c|}
\hline \multirow[t]{2}{*}{ Items } & \multirow[t]{2}{*}{ Mean } & \multirow[t]{2}{*}{ SD } & & & & & & \multirow[t]{2}{*}{1} & \multirow[t]{2}{*}{2} & \multirow[t]{2}{*}{3} & \multirow[t]{2}{*}{4} \\
\hline & & & $\mathrm{S} / \mathrm{D}$ & $\mathrm{D}$ & $\mathrm{U}$ & $\mathrm{A}$ & S/A & & & & \\
\hline $\begin{array}{l}\text { The appraisal criteria in } \\
\text { evaluating performance } \\
\text { should be made clear }\end{array}$ & 4.41 & .877 & 1.8 & 1.4 & 3.0 & 34.1 & 59.8 & - & & & \\
\hline $\begin{array}{l}\text { the appraisal results } \\
\text { should be clear and } \\
\text { reflect actual teachers' } \\
\text { performance }\end{array}$ & 4.50 & .799 & 2.2 & 1.6 & 8.4 & 28.4 & 59.2 & $.851 * *$ & - & & \\
\hline $\begin{array}{l}\text { Formal review meeting } \\
\text { is an important aspect of } \\
\text { PMS that helps in } \\
\text { improve teachers' } \\
\text { performance }\end{array}$ & 4.18 & .993 & 4.8 & 2.8 & 4.8 & 44.2 & 43.4 & $.631 * *$ & $.695^{* *}$ & & \\
\hline $\begin{array}{l}\text { The appraisal form } \\
\text { should contain clear } \\
\text { defined criteria }\end{array}$ & 4.28 & .846 & 2.4 & 2.2 & 4.6 & 44.6 & 46.2 & $.690^{* *}$ & $.769 * *$ & $.718^{* *}$ & - \\
\hline
\end{tabular}

Note: $\mathrm{N}=502$ and $* *$ correlation is significant at the 0.01 level (2-tailed) and *at the 0.05 level (2-tailed).

\section{- Fairness of PA process}

Percentage, means, standard deviation and Pearson's correlations for fairness of PA process presented on table 1.4. The average mean is 4.34 with small stander standard deviations and fairly moderate correlation.

Table 1-4 Descriptive statistics and correlations of the perception of perceived fairness of PA process

\begin{tabular}{|c|c|c|c|c|c|c|c|c|c|c|}
\hline \multirow[t]{2}{*}{ Items } & \multirow[t]{2}{*}{ Mean } & \multirow[t]{2}{*}{ SD } & & & & & & \multirow[t]{2}{*}{1} & \multirow[t]{2}{*}{2} & \multirow[t]{2}{*}{3} \\
\hline & & & S/D & $\mathrm{D}$ & $\mathrm{U}$ & A & S/A & & & \\
\hline PM process should be fair & 4.46 & .785 & 1.8 & 1.4 & 3.4 & 36.1 & 57.4 & & & \\
\hline $\begin{array}{l}\text { Appraisal should be based } \\
\text { on quantity and quality of } \\
\text { the work not on }\end{array}$ & 4.31 & .766 & 1.4 & 1.8 & 4.8 & 48.0 & 44.0 & $.808 * *$ & & \\
\hline
\end{tabular}




\begin{tabular}{|l|l|l|l|l|l|l|l|l|l|l|}
\hline personality & & & & & & & & & & \\
\hline $\begin{array}{l}\text { Head teachers should } \\
\text { receive training on } \\
\text { conducting PM process }\end{array}$ & 4.27 & .775 & 1.6 & 1.4 & 6.4 & 49.6 & 41.0 & $.808^{* *}$ & $.807^{* *}$ & - \\
\hline
\end{tabular}

Note: $\mathrm{N}=502$ and $* *$ correlation is significant at the 0.01 level (2-tailed) and *at the 0.05 level (2-tailed).

\section{- Pay for performance}

Percentage, means, standard deviation and Pearson's correlations for Pay for performance are presented on table 1.5. The average mean is 4.25 with small standard deviations and fairly moderate correlation.

Table 1-5 Descriptive statistics and correlations of the perception of Pay for performance

\begin{tabular}{|l|l|l|l|l|l|l|l|l|l|l|}
\hline \multicolumn{1}{|c|}{ Items } & Mean & SD & \multicolumn{3}{|c|}{1} & 2 & 3 \\
\cline { 1 - 6 } & & & S/D & D & U & A & S/A & & & \\
\hline $\begin{array}{l}\text { The existent of good reward } \\
\text { system motivates teachers } \\
\text { and increase their } \\
\text { commitment to achieve } \\
\text { organisational goals }\end{array}$ & 4.19 & .920 & 2.8 & 4.4 & 4.4 & 48.6 & 39.8 & & & \\
\hline $\begin{array}{l}\text { Reward teachers helps in } \\
\text { maintaining desired } \\
\text { performance levels. }\end{array}$ & 4.36 & .823 & 2.8 & 4.4 & 4.8 & 47.6 & 40.4 & $824^{* *}$ & & \\
\hline $\begin{array}{l}\text { There should be an incentive } \\
\text { scheme to high performer } \\
\text { teachers on top of annual } \\
\text { payment increase }\end{array}$ & 4.23 & .914 & 2.6 & 3.8 & 6.0 & 43.4 & 44.2 & $903^{* *}$ & $665^{* *}$ & - \\
\hline
\end{tabular}

Note: $\mathrm{N}=502$ and $* *$ correlation is significant at the 0.01 level (2-tailed) and *at the 0.05 level (2-tailed).

\section{- Training and development needs}

Percentage, means, standard deviation and Pearson's correlations for training and development needs presented on table 1.6. The average mean is 4.45 with small standard deviations and fairly moderate correlation.

Table 1-6 Descriptive statistics and correlations of the perception of training and development needs

\begin{tabular}{|l|c|c|c|c|c|c|c|c|c|c|}
\hline \multicolumn{1}{|c|}{ Items } & Mean & SD & \multicolumn{3}{|c|}{} & 1 & 2 & 3 \\
\cline { 4 - 7 } & & & S/D & D & U & A & S/A & & & \\
\hline $\begin{array}{l}\text { Teachers should be } \\
\text { provided with training } \\
\text { needs based on their PA } \\
\text { results }\end{array}$ & 4.38 & .862 & 2.8 & 1.6 & 3.8 & 38.2 & 53.6 & & & \\
\hline
\end{tabular}


International Journal of Social Science and Economic Research

ISSN: 2455-8834

Volume:05, Issue:08 "August 2020"

\begin{tabular}{|l|l|l|l|l|l|l|l|l|l|l|}
\hline $\begin{array}{l}\text { Teachers should be } \\
\text { effectively provided with } \\
\text { adequate development } \\
\text { opportunities in order to } \\
\text { improve performance. }\end{array}$ & 4.58 & .687 & 1.0 & 1.2 & 1.0 & 32.5 & 64.3 & $686^{* *}$ & & \\
\hline $\begin{array}{l}\text { Management should take } \\
\text { corrective measures such } \\
\text { as systematic remedial or } \\
\text { development support to } \\
\text { help underperforming } \\
\text { teachers }\end{array}$ & 4.40 & .925 & 3.4 & 1.8 & 5.0 & 30.9 & 59.0 & $865^{* *}$ & $745^{* *}$ & - \\
\hline
\end{tabular}

Note: $\mathrm{N}=502$ and $* *$ correlation is significant at the 0.01 level (2-tailed) and *at the 0.05 level (2-tailed).

\section{- Promotion decisions}

Percentage, means, standard deviation and Pearson's correlations for Promotion decisions are presented on table 1.7. The average mean is 4.43 with small standard deviations and fairly moderate correlation.

Table 1-7 Descriptive statistics and correlations of the perception of Promotion decisions

\begin{tabular}{|c|c|c|c|c|c|c|c|c|c|c|}
\hline \multirow[t]{2}{*}{ Items } & \multirow[t]{2}{*}{ Mean } & \multirow[t]{2}{*}{ SD } & & & & & & \multirow[t]{2}{*}{1} & \multirow[t]{2}{*}{2} & \multirow[t]{2}{*}{3} \\
\hline & & & S/D & $\mathrm{D}$ & $\overline{\mathrm{U}}$ & $\mathrm{A}$ & S/A & & & \\
\hline $\begin{array}{l}\text { Promotion decisions should } \\
\text { be based on performance } \\
\text { appraisal results }\end{array}$ & 4.45 & .802 & 1.4 & 2.2 & 4.2 & 32.3 & 60.0 & - & & \\
\hline $\begin{array}{l}\text { Promotion decision should } \\
\text { be fair and not based on } \\
\text { personal relationships }\end{array}$ & 4.44 & .741 & 0.6 & 2.6 & 3.8 & 38.6 & 54.4 & $.703 * *$ & & \\
\hline $\begin{array}{l}\text { Fair promotion decision } \\
\text { motivates teachers increase } \\
\text { their commitment to achieve } \\
\text { organisational goals }\end{array}$ & 4.42 & .878 & 1.8 & 4.4 & 2.0 & 32.9 & 59.0 & $.627 * *$ & $677 * *$ & - \\
\hline
\end{tabular}

Note: $\mathrm{N}=502$ and $* *$ correlation is significant at the 0.01 level (2-tailed) and *at the 0.05 level (2-tailed).

\section{- Management commitment}

Percentage, means, standard deviation and Pearson's correlations management commitmentare presented on table 1.8. The average mean is 4.31 with small standard deviations and fairly moderate correlation. 
International Journal of Social Science and Economic Research

ISSN: 2455-8834

Volume:05, Issue:08 "August 2020"

Table 1-8 Descriptive statistics and correlations of the perception of Management commitment

\begin{tabular}{|l|c|c|c|c|c|c|c|c|c|c|}
\hline \multicolumn{1}{|c|}{ Items } & Mean & SD & \multicolumn{3}{c|}{} & 1 & 2 & 3 \\
\cline { 4 - 8 } & & & S/D & D & U & A & S/A & & & \\
\hline $\begin{array}{l}\text { Management should be } \\
\text { committed to successful } \\
\text { implementation of PMS }\end{array}$ & 4.29 & .981 & 3.4 & 4.0 & 5.4 & 34.3 & 53.0 & & & \\
\hline $\begin{array}{l}\text { Head teachers should be held } \\
\text { accountable for ensuring } \\
\text { completion of each step of } \\
\text { PMS }\end{array}$ & 4.42 & .804 & 1.0 & 3.4 & 4.0 & 36.1 & 55.6 & $.784^{* *}$ & & \\
\hline $\begin{array}{l}\text { Teachers and school } \\
\text { management should have } \\
\text { ownership to the PMS and } \\
\text { view it as one of their critical } \\
\text { responsibilities }\end{array}$ & 4.23 & 1.01 & 4.6 & 3.6 & 4.6 & 38.8 & 48.4 & $.714^{* *}$ & $.714^{* *}$ & - \\
\hline
\end{tabular}

Note: $\mathrm{N}=502$ and $* *$ correlation is significant at the 0.01 level (2-tailed) and *at the 0.05 level (2-tailed).

\section{- Teachers involvement in the development of PM}

Percentage, means, standard deviation and Pearson's correlations for teachers' involvement in the development of PM are presented on table 1.9. The average mean is 4.55 with small standard deviations and fairly moderate correlation.

Table 1-9 Descriptive statistics and correlations of the perception of teachers' involvement in the development of PM

\begin{tabular}{|c|c|c|c|c|c|c|c|c|c|c|c|}
\hline \multirow[t]{2}{*}{ Items } & \multirow[t]{2}{*}{ Mean } & \multirow[t]{2}{*}{ SD } & \multicolumn{5}{|c|}{ Percentage } & \multirow[t]{2}{*}{1} & \multirow[t]{2}{*}{2} & \multirow[t]{2}{*}{3} & \multirow[t]{2}{*}{4} \\
\hline & & & S/D & $\mathrm{D}$ & $\mathrm{U}$ & A & S/A & & & & \\
\hline $\begin{array}{l}\text { Teachers should be involved } \\
\text { in setting goals and } \\
\text { objectives }\end{array}$ & 4.72 & .815 & 2.2 & 2.2 & 2.4 & 2.8 & 6.0 & - & & & \\
\hline $\begin{array}{l}\text { Teachers should be involved } \\
\text { in setting performance } \\
\text { criteria that are used during } \\
\text { the evaluation period }\end{array}$ & 4.67 & .728 & 1.6 & 1.6 & 1.2 & 2.2 & 19.0 & $.708^{* *}$ & - & & \\
\hline $\begin{array}{l}\text { Teachers should be involved } \\
\text { during the development of } \\
\text { PMS }\end{array}$ & 4.42 & .820 & 2.2 & 2.2 & 1.8 & 2.8 & 37.8 & $.534 * *$ & $.608 * *$ & - & \\
\hline $\begin{array}{l}\text { The involvement of teachers } \\
\text { in developing PM improve } \\
\text { teachers attuite towards PM }\end{array}$ & 4.40 & .842 & 2.2 & 2.2 & 1.8 & 4.6 & 37.5 & $.471 * *$ & $.626 * *$ & $.775 * *$ & \\
\hline
\end{tabular}

Note: $\mathrm{N}=502$ and ${ }^{* *}$ correlation is significant at the 0.01 level (2-tailed) and *at the 0.05 level (2-tailed).

\section{- Teachers awareness of the process}


International Journal of Social Science and Economic Research

ISSN: 2455-8834

Volume:05, Issue:08 "August 2020"

Percentage, means, standard deviation and Pearson's correlations for teachers' awareness of the processare presented on table 1.10. The average mean is 4.32 with small standard deviations and fairly moderate correlation.

Table 1-10 Descriptive statistics and correlations of the perception of teachers' awareness of the process

\begin{tabular}{|l|l|l|l|l|l|l|l|l|l|l|l|}
\hline \multicolumn{1}{|c|}{ Items } & Mean & SD & \multicolumn{6}{c|}{ Percentage } & 1 & 2 & 3 \\
\cline { 4 - 8 } & & & S/D & D & U & A & S/A & & & \\
\hline $\begin{array}{l}\text { The purpose of the } \\
\text { performance management } \\
\text { system should be } \\
\text { communicated to the } \\
\text { teachers. }\end{array}$ & 4.42 & .846 & 2.2 & 3.0 & 3.0 & 34.5 & 57.4 & & & \\
\hline $\begin{array}{l}\text { Teachers should receive } \\
\text { training PM process to } \\
\text { improve the awareness of } \\
\text { PMS }\end{array}$ & 4.18 & .897 & 3.2 & 3.0 & 4.6 & 50.8 & 38.4 & $.587^{* *}$ & & & \\
\hline $\begin{array}{l}\text { Teachers should understand } \\
\text { the purpose of PMS }\end{array}$ & 4.37 & .837 & 2.4 & 1.6 & 4.2 & 40.4 & 51.4 & $.703^{* *}$ & $.726^{* *}$ & - \\
\hline
\end{tabular}

Note: $\mathrm{N}=502$ and $* *$ correlation is significant at the 0.01 level (2-tailed) and *at the 0.05 level (2-taied)

\subsection{Assessment of validity}

In order to examine the validity convergent validity, discriminant validity should be measured. Convergent validity is measured to check the extent to which particular constructs and related observed variables share greater variance in common. To assess the convergent validity of every construct, the average variance extracted (AVE), construct factor loading, and construct reliability estimation are employed (Hair et al., 2010). Hair, et al. (2010) further suggested that the ideal standardised loading estimates should be 0.7 or higher, but noted factor loading with score of 0.50 and greater as very significant. The AVE estimation should be greater than 0.5 to show adequate convergent validity. In this research, all loadings were greater than 0.50 and considered to be significant (see figure 2); thus, convergent validity was established, as Dunn, et al. (1994) suggested that 'if the factor loadings are statistically significant, then convergent validity exists'. The average variance extracted is shows that the AVE estimation is greater than 0.5. Thus, the results demonstrate a high level of convergent validity of the latent construct used in the model.

\subsection{Structure equation modelling}

The structural equation modelling (SEM) was used to analyse the data in order to test the hypotheses arising from the conceptual framework. The data was employed to perform with 
International Journal of Social Science and Economic Research

ISSN: 2455-8834

Volume:05, Issue:08 "August 2020"

statistical analysis after checking and having a better understanding using SPSS. By jointly modelling the relationship between independent and dependent variables, SEM allows analysis of related questions in a single analysis. A two-stages approaches were used to analyse the structural equation modelling proposed by Anderson and Gebing (1988). The first stage is to carry out the measurement model evaluation to test the reliability and validity of the constructs by using the confirmatory factor analysis (CFA)(see figure 1). The second stage is the structural model procedure which is employed to determine the hypothesized correlation between the constructs for the suggested model.

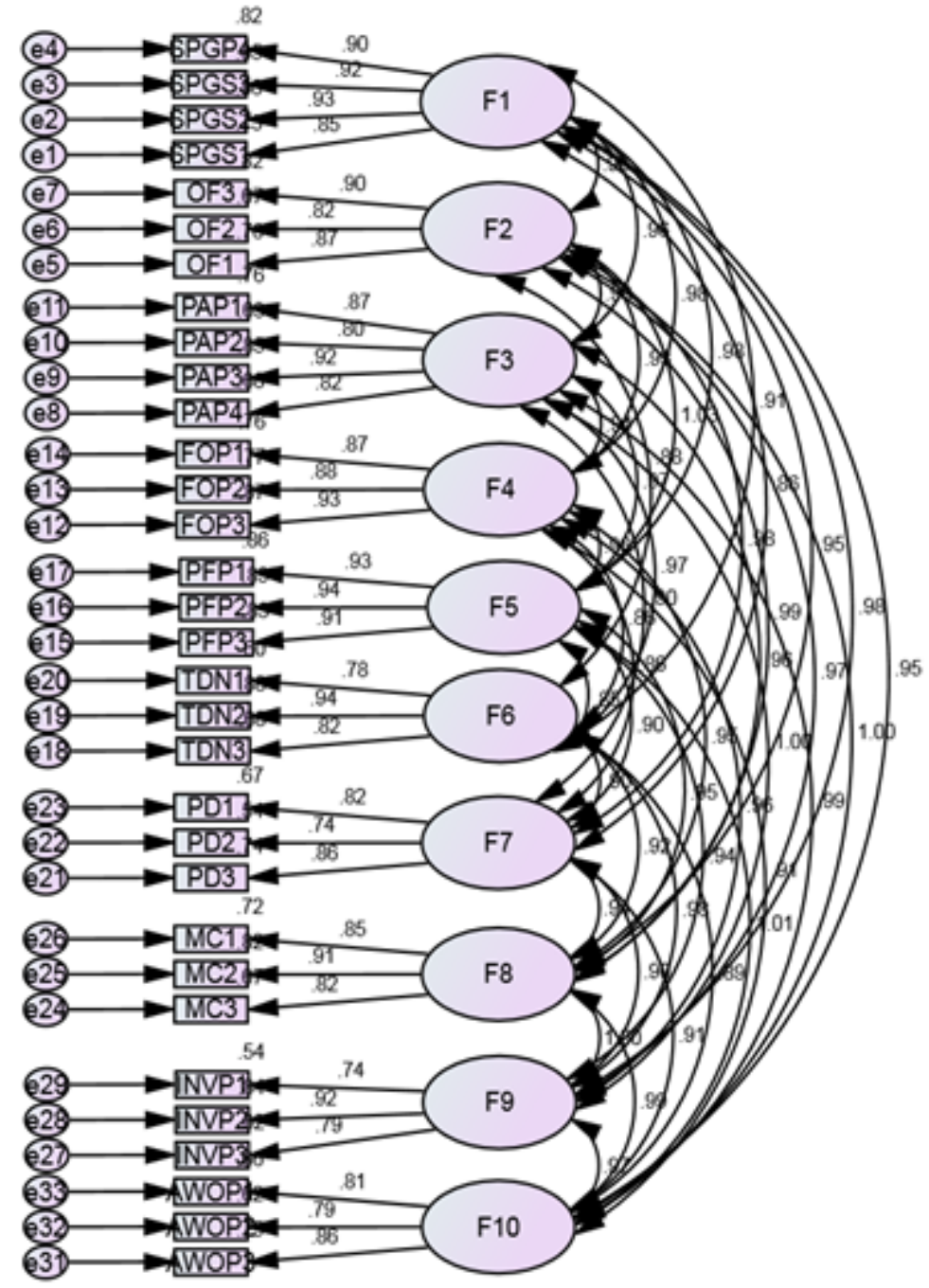

Figure 2 Path diagram showing initial hypothesised first-order confirmatory factor analysis model with standardised coefficients (from AMOS) 
International Journal of Social Science and Economic Research

ISSN: 2455-8834

Volume:05, Issue:08 "August 2020"

\subsection{Performance of the model}

A number of fit indices such as Chi square/ Degrees of freedom ( $\chi 2 / \mathrm{df})$, Comparative fit index (CFI), Normative fit index (NFI), Incremental fit index (IFI), Tucker-Lewis Index (TLI) and Root mean square error of approximation (RMSEA) were used for analysing the performance of the measurement model (Byrne, 2010). All the latent variables were measured using the original studies as far as possible. The primary results showed that (table 1.11) the chi-square test was significant as well as the RMSEA, but CFI, NFI, and GFI were a little lower than the recommended values. The model was again reassessed, and confirmatory factor analysis was reperformed to ensure a better fit. The results of the model showed that the fit indices were got better and, therefore, the revised model showed a better fit to the data (table 1.12).

Table 1-11 Model fit indices of structural model

\begin{tabular}{|l|l|l|l|l|l|l|l|l|l|}
\hline$\chi \mathbf{2}$ & $\mathbf{D F}$ & $\mathbf{p}$ & $\boldsymbol{\chi 2} / \mathbf{d f}$ & CFI & GFI & NFI & RAMSA & IFI & TLI \\
\cline { 4 - 9 } & & & $<\mathbf{3}$ & $\mathbf{2 0 . 9 0}$ & $\mathbf{2 0 . 9 0}$ & $\mathbf{2 0 . 9 0}$ & $\mathbf{2 0 . 1 0}$ & $\mathbf{2 0 . 9 0}$ & $\mathbf{. 9 5 0}$ \\
\hline 2288.462 & 372 & .001 & 6.15 & .922 & 791 & .911 & .102 & .923 & 882 \\
\hline
\end{tabular}

[Note: $\chi^{2}=$ Chi-Square; $\mathrm{DF}=$ Degrees of Freedom; $\mathrm{p}=$ Significance; $\mathrm{CFI}=$ Comparative Fit Index; RMSEA=Root Mean Square Error of Approximation; TLI=Tucker-Lewis Index, Normed Fit Index NFI, Incremental fit index (IFI)]

Table 1-12 Model fit indices of structural model

\begin{tabular}{|l|l|l|l|l|l|l|l|l|l|}
\hline $\boldsymbol{2} \mathbf{2}$ & $\mathbf{D F}$ & $\mathbf{p}$ & $\boldsymbol{\chi 2} / \mathbf{d f}$ & CFI & GFI & NFI & RAMSA & IFI & TLI \\
\cline { 4 - 9 } & & & $<\mathbf{3}$ & $\mathbf{2 0 . 9 0}$ & $\mathbf{2 0 . 9 0}$ & $\mathbf{2 0 . 9 0}$ & $\mathbf{2 0 . 1 0}$ & $\mathbf{2 0 . 9 0}$ & $\mathbf{. 9 5 0}$ \\
\hline 2182.640 & 314 & .001 & 6.951 & .926 & .800 & .915 & .109 & .927 & .883 \\
\hline
\end{tabular}

[Note: $\chi 2=$ Chi-Square; DF=Degrees of Freedom; $\mathrm{p}=$ Significance; $\mathrm{CFI}=$ Comparative Fit Index; RMSEA=Root Mean Square Error of Approximation; TLI=Tucker-Lewis Index, Normed Fit Index NFI, Incremental fit index (IFI)]

\subsection{Hypothesis testing}

This section provides a brief summary of the hypotheses proposed and states whether each is supported by the data or not. Independent constructs were strategic planning and goals settings, feedback, performance appraisal, fairness of performance appraisal, pay for performance, training and development, promotion decisions, management commitment, involvement of PM process and understanding the purpose of PMS, while dependent variable consisted of satisfaction with performance management. Ten hypotheses (H1, H2, H3, H4, H5, H6, H7, H8, 
$\mathrm{H} 9, \mathrm{H} 10)$ ware displayed by causal paths which used to test the relationships between the latent constructs. The results showed that all hypotheses, were statistically significant and, thus, accepted (See figure 3).

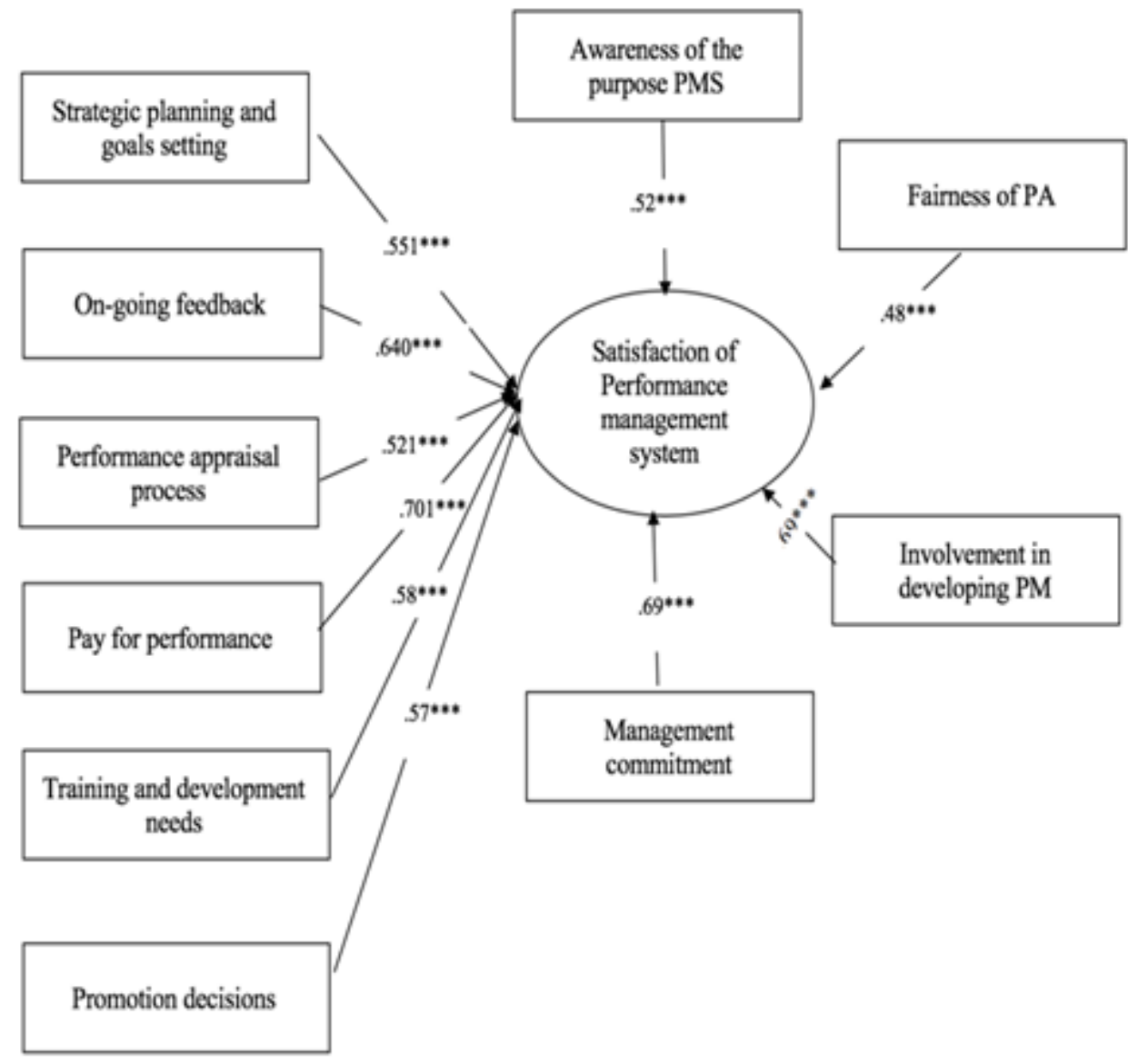

Figure 3: Best fit model of study

\section{DISCUSSION AND IMPLICATION}

PM has quite recently become a central focus of both practitioners and researchers. It is now seen as a strategic initiative to enhance employee performance and, consequently, that of the organisation (Combs et al., 2006). However, organisations should take more care to use an effective PMS in order to improve the performance of organisations and employees. The main aim of this study is to examines the determinants of individual-level performance satisfaction of 


\section{International Journal of Social Science and Economic Research}

ISSN: $2455-8834$

Volume:05, Issue:08 "August 2020"

teachers employed by the Saudi Ministry of Education. The dearth of studies which examine the factors affecting teachers' performance in Saudi setting was the motivating factor to do this research. As part of the assessment of the research objectives a conceptual model was developed in order to examine the factors affecting teachers' satisfaction about PM in the Saudi Ministry of Education. The study tests the model to assess teachers' satisfaction of performance management by employing SEM approach.SEM syndicates the strength of factor analysis and path analysis. It allows to test whether observed variables completely define latent variables or not. It shows whether the proposed model is appropriate to represent a proposed conceptual relationship between the variables or not. The results of CFA indicate that the observed variables are appropriate enough to represent different latent variables, that is, strategic planning and goals settings, feedback, performance appraisal, fairness of performance appraisal, pay for performance, training and development, promotion decisions, management commitment, involvement of PM process and understanding the purpose of PMS, to increase teachers' satisfaction with performance management. The findings of structural model analysis show that the proposed model for teachers' satisfaction with performance management fits well.In addition, the proposed hypotheses evaluating the relationships between the variables are statistically supported showing that the model is appropriate to examine satisfaction with the PMS. The finding show that an accurate PMS should comprise aspects such as strategic planning and goal-setting, ongoing feedback, clear and balanced PAs, fairness of PAs, pay for performance, training and development, promotion decisions, management commitment, involvement in the PM process and understanding of the purpose of the PMS. Overall, the PMS construct that included the examined factors was found to be significantly and positively related to satisfaction with the PMS. The proposed model includes key factors for the success of the PM. Therefore, the results of the study show the way for programme designers and education planners to manage an effective tool.

\section{CONCLUSION}

This study provided an empirical study and theoretical vision by developing a proposed model that identified the most important possible determinants, from the viewpoint of teachers, that lead to teacher satisfaction with the PMS; the validity of this model was tested in the Saudi setting. Furthermore, an investigation was conducted that revealed how effective PM can lead not only to teacher satisfaction with PM but also to improved performance. The investigation showed that how these outcomes could be related to variables such as strategic planning and goal-setting; ongoing feedback; PA processes; pay for performance; training and development needs; promotion; management commitment; the perceived fairness of PM; teachers' involvement in developing PM; and teachers' awareness of the purpose of PMSs. 
International Journal of Social Science and Economic Research

ISSN: 2455-8834

Volume:05, Issue:08 "August 2020"

\section{REFERANCE}

- Abu Mansor, N., Chakraborty, A, Yin, T., \&Mahitapoglu, Z. (2012). Organizational Factors Influencing Performance Management System in Higher Educational Institution of South East Asia. Procedia - Social and Behavioural Sciences, 40, 584 - 590.

- Adhikari, R. (2010). Human resource development (HRD) for performance management: the case of Nepalese organizations. International Journal of Productivity and Performance Management, 59 (4), 306-324.

- Aguinis, H. (2015). Performance management (4th edition). Upper Saddle River, NJ,:Pearson Prentice Hall.

- Anderson, G. C. (1993). Managing Performance Appraisal Systems. Cambridge, MA: Blackwell Business.

- Anderson, J. C., \&Gerbing, D. W. (1988). Structural Equation Modelling in Practice: A Review and Recommended Two-Step Approach. Psychological Bulletin, 103(3), 411423.

- Armstrong, M. (2009). Performance management: Key strategies and guidelines (3rd ed.). London: CIPD

- Ashford, S. J., and Cummings, L. L. (1983). Feedback as an individual resource: Personal strategies of creating information. Organizational behavior and human performance, 32(3), 370-398.

- Bhatia SK (2006) Human Resource Management - A Competitive Advantage - Concepts, Strategies, Challenges. India: Jain book Agency.

- Boswell, W.R. \& Boudreau, J.W. (2002 'Separating the developmental and evaluative performance appraisal uses'. Journal of Business and Psychology, 16(3), 391-412.

- Brudan, A. (2010). Rediscovering performance management: systems, learning and integration. Measuring Business Excellence. 14 (1),109-123.

- Byrne, B. M. (2010). Structural equation modelling with AMOS: Basic concepts, applications, and programming 2nd Edition. Routledge Taylor \& Francis Group.

- Cardy, R.L. and Dobbins, G.H. (1994) Performance appraisal: Alternative perspectives. Cincinati, OH: South-Western Publishing.

- Cawley, B. D., Keeping, L. M., \& Levy, P. E. (1998). Participation in the performance appraisal process and employee reactions: A meta-analytic review of field investigations. Journal of Applied Psychology, 83(4), 615-633.

- Coelho, J. F. G.M.; Moy, D. 2003. The new performance evaluation methodology and its integration with management systems. The TQM Magazine, 15(1), 204-208. 


\section{International Journal of Social Science and Economic Research}

ISSN: $2455-8834$

Volume:05, Issue:08 "August 2020"

- Combs J, Liu Y, Hall A \&Ketchen D (2006) How much do high-performance work practices matter? Ameta-analysis of their effects on organizational performance. Personnel Psychology 59(3), 501-528.

- Darling-Hammond, L., LaPointe, M., Meyerson, D., T, O. M., \& Cohen, C. (2007). Preparing School Leaders for a Changing World: Lessons from Exemplary Leadership Development Programs. Stanford, CA: Stanford University, Stanford Educational Leadership Institute.

- De waal, A. \&Counet, H. (2009). Lessons learned from performance management systems implementations. International Journal of Productivity and Performance Management, 58 (4): 367-390.

- DeCenzo, D., Robbins, S., Verhulst, S. and DeCenzo, D. (2015). Human resource management. United state: Wiley.

- DeNisi, AS \&Sonesh, S 2011, 'The appraisal and management of performance at work', in S Zedeck (ed.), APA handbook of industrial and organizational psychology, American Psychological Association, Washington, pp. 255-279.

- du Plessis, M. (2007), "The role of knowledge management in innovation", Journal of Knowledge Management, 11(4),20-29.

- Elliott, K. (2015). Teacher Performance Appraisal: More about Performance or Development? Australian Journal of Teacher Education, 40(9). 102-116.

- Fryer, K., Antony, J. \& Ogden, S. (2009). Performance management in the public sector. International Journal of Public Sector Management, 22(6): 478-498.

- Fullan, M. \& Hargreaves, A. (1996). What's worth fighting for in your school? Toronto, Elementary Teachers' Federation of Ontario,New York: Teachers College Press; Buckingham, Open University Press.

- Gentle, D. (2001). 'Managing performance management in the performing school'. In D. Gleeson \& C. Husbands (Eds) The performing school: Managing teaching and learning in a performance culture,20-32. London: Routledge Falmer.

- Grint, K. (1993). What's Wrong with Performance Appraisals? A Critique and A Suggestion.Human resource management journal, 3(3),61-77.

- Hair, J.F., Black, W.C., Babin, B.J., \& Anderson, R.E. (2010). Multivariate Data Analysis 7th Edition. New Jersey: Prentice Hall, Upper Saddle River.

- Henderson, R. I. (1984). Practical guide to performance appraisal. Virginia: Reston Publishing.

- Heneman, R. L. \& Gresham, M. T. (1998). Performance-based pay plans. In J. W. Smither (Ed.), Performance appraisal: State-of-the-art in practice. San Francisco: Jossey-Brass. 


\section{International Journal of Social Science and Economic Research}

ISSN: $2455-8834$

Volume:05, Issue:08 "August 2020"

- Igbojekwe, A \& Ugo-Okoro, P. (2015). Performance Evaluation of Academic Staff in Universities and Colleges In Nigeria: The Missing Criteria. International Journal of Education and Research, 3 (3). 627-640.

- Ilgen, D.R. \& Schneider, J (1991) 'Performance measurement: A multi-discipline view', in Cooper, C.L. and Robertson, I.T. (eds) International Review of Industrial and Organisational Psychology, Chicester: Wiley.

- Jones, R.E. (1997), Teacher participation in decision making - its relationship to staff morale and student achievement, Education, 118 (1), 76-82.

- Kabak, E, K, Gocer, K, S, A, Kucuksoylemez, S, Tuncer, G, (2014) "strategies for employee job satisfaction: a case of service sector," Procedia - Social and Behavioral Sciences 150, 1167 - 1176.

- Kavanagh, P., Benson, J. and Brown, M (2007) Understanding performance appraisal fairness.Asia Pacific Journal of Human Resources, 45(2), 132-150.

- Lawler, E. (1967). The multitrait-multirater approach to measuring managerial job performance. Journal of Applied Psychology, 51(5), 369-381.

- Lawler, E. E. III, Mohrman, S. A., and Ledford, G. E., Jr. (1995). Creating high performance organizations: Practices and results of employee involvem0ent and total quality management in Fortune 1000 companies. San Francisco: Jossey-Bass.

- Lehman, P. H., \& Geller, E. S. (2004). Behavior Analysis and Environmental Protection: Accomplishments and Potential for More. Behavior and Social Issues, 13(1), 13-33.

- Locke, E.A and Latham, G.P (2002) 'Building a practically useful theory of goal-setting and task motivation'. American Psychologist, 57 (9), 705-717.

- McGregor, D (1957) An uneasy look at performance appraisal, Harvard Business Review,35(3), 89-94.

- McMahon, G., (2009). Successful performance management: Effective strategy, best practice and key skills. Dublin: Liffey Press.

- Mo, K. W., Corners, R. \&McComick, J (1998). Teacher appraisal in Hong Kong selfmanaging schools. Factors for effective practices. Journal of Personnel Evaluation in Education, 12(1), 19-42.

- Moon, J.M. (2000) 'Organisational commitment revisited in New Public Management: Motivation, organisational culture, sector, and managerial level. Public Performance and Management Review, 24 (2). 177-194.

- Murlis, H. (1992). 'Performance -related pay in the context of performance management', in H. Tomlinson (ed.). Performance Related Pay in Education. London: Routledge.

- Murnane, R. J. \& Cohen, D. K. (1986). 'Merit pay evaluation problem: why most merit pay plans fail and a few survive'. Harvard Educational Review, 56 (1), 1-17. 


\section{International Journal of Social Science and Economic Research}

ISSN: $2455-8834$

Volume:05, Issue:08 "August 2020"

- Murphy, K.R. and Cleveland, J.N. (1995) Understanding Performance Appraisal. Social, Organizational and Goal Setting, Thousand Oaks: Sage Publications.

- Patrick, I, \&Ozturen, A. (2014). Perception of Justice in Performance Appraisal and Effect on Satisfaction: Empirical Findings from Northern Cyprus Banks. Procedia Economics and Finance, 23964 - 969.

- Prowse, P. \& Prowse, J. (2009). The dilemma of performance appraisal. Measuring Business Excellence, 13(4), 69-77.

- Raziq, A., \&Maulabakhsh, R. (2015) Impact of Working Environment on Job Satisfaction. Procedia Economics and Finance. 23(15), 717 - 725.

- Roberson, Q. M., \& Stewart, M. M. (2006). Understanding the motivational effects of procedural and informational justice in feedback processes. British Journal of Psychology, 97(3), 281-298.

- Ryan, R.M., \& Deci, E.L. (2000). Intrinsic and extrinsic motivations: Classic dentitions and new directions. Contemporary Educational Psychology, 25(1), 54-67.

- Steelman, L. and Rutkowski, K. (2004). 'Moderators of Employee Reactions to Negative Feedback'. Journal of Managerial Psychology, 19(1), 6-18.

- Stiggins, R.J. \&Bridgeford, N.J. (1985), Performance assessment for teacher development. Educational Evaluation and Policy Analysis, 7 (1), 85-97.

- Stone, R. J. (2008). Managing human resources. Milton Qld: John Wiley \& Sons.

- Taylor, M., Tracy, K, Renard, M., Harrison, J and Carroll, S (1995). 'Due process in performance appraisal: A quasi-experiment in procedural justice'. Administrative Science Quarterly, 40(3), 495-523.

- Tomlinson, H. (2000). Proposals for performance-related pay for teachers in English Schools. School leadership and management Formerly School Organisation, 20(3), 281298

- Vroom, V (1964). Work and motivation. New York: Wiley.

- Walters, M. (1995). The Performance Management Handbook. London: Institute of Personnel and Development.

- Williams, R. (2002). Managing employee performance: Design and implementation in organizations. London: South Western Cengage Learning.

- Wragg, E., Haynes, G., Wragg, C., \& Chamberlin, R. (2004). Performance pay for teachers: the views and experiences of heads and teachers. London, UK: Routledge Falmer. 